\title{
Isolation and Identification of Microorganisms Including Lactic Acid Bacteria and Their Use in Microbial Deacidification of Wines from Domestic Vineyards
}

\author{
IWONA DROŻDŻ*, MAŁGORZATA MAKAREWICZ and TADEUSZ TUSZYŃSKI \\ University of Agricultural in Kracow, Department of Fermentation Technology \\ and Technical Microbiology, Cracow, Poland
}

Submitted 26 June 2012, revised 21 February 2013, accepted 17 April 2013

Abstract

The aim of this study was to identify various bacteria isolated from grapes and their wines. Additionally we investigated the capacity of lactic acid bacteria for microbiological deacidification of wines produced in Poland. We have identified Oenococcus oeni, Lactobacillus acidophilus and Lactobacillus delbrueckii. During the microbial deacidification process, we observed decreases of total acidity and increases of volatile acidity, with statistically significant changes noted for O. oeni in Marechal Foch and Seyval Blanc, and for Lb. acidophilus in Frontenac. On the other hand, a statistically significant increase in $\mathrm{pH}$ was observed in Marechal Foch and Seyval Blanc following deacidification by O. oeni.

Key words: lactic acid bacteria, malolactic fermentation, wine

Wine is the final product of a complex process in which different groups of microorganisms are involved: yeasts, bacteria and molds. The wines obtained from national raw materials are characterized by high acidity. High concentrations of organic acids in wines can be a problem when introducing the final product for sale. Reduction of the total acidity of wine can be achieved by chemical or biological deacidification. An appropriate choice of strains for malolactic fermentation (MLF) can reduce the acidity of the wine (Henick-Kling, 1995). The microorganisms which reduce the acidity of wines are mainly species naturally occurring on the surface of the fruit, this process is often performed by lactic acid bacteria (LAB).

The most common bacteria present on grapes are Oenococcus oeni, Leuconostoc mesenteroides, Pediococcus parvulus, $P$. pentosaceus, $P$. damnosus and different species of Lactobacillus (L. brevis, L. plantarum, L.fermentum, L. buchneri, L. hilgardii and L. trichodes) (Fleet, 2007; Du Toit et al., 2011). Malolactic fermentation, in addition to deacidification, affects the flavor characteristics of wine and has a fully positive role in microbial stabilization (Pozo-Bayon et al., 2005).

The process of deacidification and starter cultures of LAB (O. oeni and Lactobacillus spp.) (Du Toit et al., 2011) are well known and used in southern Europe. Poland is among the countries with a cool climate for wine. The study of microflora of grapes and the control process of wine production are still in progress. It would be ideal to isolate the microflora responsible for deacidification process and obtain stable starter cultures for microbial deacidification of cool climate wine. The authors believe that this would be the most effective process of deacidification of wines, which will result in the preferred sensory properties of beverages, giving them a specific and regional character. The aim of this study was to identify various bacteria, including lactic acid bacteria, present on grapes. We also studied the capacity of lactic acid bacteria for malolactic fermentation and their use in microbial deacidification of cold climate wine.

The tested grapes were washed in $10 \mathrm{ml}$ of Ringer's solution. $1 \mathrm{ml}$ of the eluate was plated onto agar. Each culture was taken in duplicate. Microorganisms were plated on nutrient dextrose agar (AO) and MRS agar. The plates with $\mathrm{AO}$ were incubated for $24 \mathrm{~h}$ and those with MRS for $72 \mathrm{~h}$ at $32^{\circ} \mathrm{C}$. Pure cultures were incubated at $32^{\circ} \mathrm{C}$ for $24 \mathrm{~h}$ and then stored at $+4^{\circ} \mathrm{C}$. Bacterial cultures were analyzed macroscopically and microscopically (Gram stain, Nikon Eclipse 1000x magnification microscope, with a Moticam 2000 digital camera and the program Tomic Live Imaging). Biochemical test for catalase and microtests of fermentation by Kocwa (Burbianka et al., 1971) were performed. For testing

\footnotetext{
* Corresponding author: I. Drożdż, University of Agricultural in Kracow, Department of Fermentation Technology and Technical Microbiology, Balicka 122, 30-149 Kraków, Poland; phone: +48 126624793; fax: +48 126624798; e-mail: iwona.m.drozdz@gmail.com
} 
of fermentation we used glucose, galactose, maltose, mannose, fructose, ribose, arabinose, and lactose, with $\mathrm{CaCO}_{3}$ as an indicator. After incubation at $32^{\circ} \mathrm{C}$ for $24 \mathrm{~h}$, the appearance of a halo around the colony indicates the ability to ferment the tested sugar.

Microorganisms from wines were plated on $\mathrm{AO}$ and GYC medium (for acetic acid bacteria), or MRS and substrate for Leuconostoc. The cultures were incubated for $24 \mathrm{~h}$ at $32^{\circ} \mathrm{C}$. Samples of wine were diluted to $10^{\circ}$, $10^{-1}$ and $10^{-2}$ in sterile physiological saline. Pure cultures were derived for further research, and stored at $4^{\circ} \mathrm{C}$. Microorganisms were analyzed macroscopically and microscopically (Gram stain, Schaeffer-Fulton (microscope magnification $1000 \mathrm{x})$ ). The following biochemical tests were performed: test of catalase and microtests of fermentation by Kocwa (Burbianka et al., 1971), to determine the capacity of bacterial strains for degradation of fructose, sucrose, maltose, lactose, L-arabinose, glycerol, mannitol and raffinose. Lactic acid bacteria, acetic acid bacteria and Enterobacteriaceae were identified. The pure cultures of bacteria were identified with the key of Dworkin et al. (2006).

Colonies identified using the API 50CH (BioMerieux) for identification of lactic acid bacterial species (Gotcheva et al., 2000). The cultures of LAB were passaged on slants and liquid MRS medium, with limited access of oxygen at $28^{\circ} \mathrm{C}$. Two of the isolated strains of LAB were used for microbiological deacidification of wine.

Malolactic fermentation was carried out on three varieties of wine, that came from the vineyards Garlica Murowana (UR in Krakow). Red wines were made from Marechal Foch and Frontenac strains and white wine from Seyval Blanc strain. All three wines were fermented by MLF using two strains of lactic acid bacteria, O. oeni $\left(10^{9} \mathrm{cfu} / \mathrm{cm}^{3}\right)$ and Lactobacillus acidophilus $\left(10^{9} \mathrm{cfu} / \mathrm{cm}^{3}\right)$. The cell density was determined using a McFarland densitometer (Den-1B, Biosan). The wine, in quantities of $300 \mathrm{ml}$, was subjected to deacidification for $2-3$ weeks at $20^{\circ} \mathrm{C}$. During the process, wine acidity (PN-90/A-79120/07), volatile acidity (PN90/A-79120/08), alcohol content (PN-90/A-79120/04) and $\mathrm{pH}$ were measured.

All experiments were performed in three replicates, for each sample. To determine the significance of differences between mean values, multivariate analysis of variance with post hoc Dunn's multiple comparisons test was performed. Distribution of normality was determined by Friedman test using the program InStat3 (Graph Pad Software, Inc., San Diego, CA).

We identified 30 bacterial isolates from different varieties of grapes. Six tested grapes are used for the production of red wine (Marechal Foch, Leon Millet, Alden, Frontenac, Rondo, Swenson Red) and five for white wines (Prim, Muskat Odessa, Aurora, Perle von
Alzey, Bianca). The grapes were obtained from the vineyard Golesz (Podkarpacie province). Gram positive bacilli (Bacillus spp., 56.5\%), and cocci (Micrococcus spp., 10\%), Gram positive and catalase negative lactic acid bacteria (Lactobacillus spp., 7\%) and Gram-negative bacilli (26.5\%) were identified. The identified bacteria were not typical representatives for these grapes. According to current knowledge, we expected mainly LAB and acetic acid bacteria (Du Plessis et al., 2004; Du Toit et al., 2011), which constitute the dominant microflora. However, other species of bacteria such as Micrococcus spp. and Bacillus spp. (Ponce, 2003), Alicyclobacillus spp. (Parish and Goodrich, 2005) and anaerobic Clostridium spp. (Irudayaraj et al., 2002) were reported.

We analyzed 42 colonies of bacteria isolated from the wines and identified cocci (7\%), Bacillus (35\%), lactic acid bacteria (5\%), acetic acid bacteria (17\%) and Gram-negative Enterobacteriaceae (36\%). Among the isolated strains of LAB we detected Lactobacillus delbrueckii and Oenococcus oeni, acetic bacteria Acetobacter aceti, A. pasteurianus, Gluconacetobacter liquefaciens, G. hansenii and G. xylinus. Wine is a specific ecosystem and therefore it is not always possible to create laboratory conditions for breeding these microorganisms. Studies on isolation of microorganisms from a variety of wines allow one to characterize the microflora of grapes and interactions between bacteria, yeasts and molds (Fleet, 2007).

The lactic acid bacteria were tested for their biological suitability for the process of deacidification of wine. Wines produced from grapes grown in Poland and in other regions with colder climates are characterized by higher contents of organic acids (Liu, 2002). At present, consumers around the world prefer wine with a fruity character and moderate acidity, which means that biological deacidification has become an important issue in the production of wines. Therefore, searching for appropriate strains to serve as new starter cultures, able to reduce the acidity of the wine and increase its quality, is an important direction of research in Poland.

Our test results confirmed the presence of O. oeni, Lactobacillus acidophilus and Lactobacillus delbrueckii, although one species could not be identified. Under laboratory conditions, only O. oeni and L. acidophilus was able to grow and was used for microbiological wine deacidification.

Wine selection was not accidental. These were wines produced from fruit harvested during frequent rain, low temperatures and low sunlight. Both strains of bacteria caused a change in total acidity, volatile acidity, and $\mathrm{pH}$. This research indicates that the degree of deacidification depends on the type of wine and grape varieties.

Total acidity determines the content of chemical substances of an acidic nature. It is a very important parameter influencing the flavor characteristics of the 
Table I

The profile of total acidity, volatile, and $\mathrm{pH}$ of the wines tested

(the value are given as mean and standard deviation; ${ }^{\star} \mathrm{p}<0.05 \mathrm{vs}$. control)

\begin{tabular}{|l|c|c|c|}
\hline \multicolumn{1}{|c|}{ Wine } & Control & $\begin{array}{c}\text { Deacidification by } \\
\text { Oenococcus oeni }\end{array}$ & $\begin{array}{c}\text { Deacidification by } \\
\text { Lb. acidophilus }\end{array}$ \\
\hline \multicolumn{4}{|c|}{ Total acidity [tartaric acid g/L] } \\
\hline Marechal Foch - red & $9.63 \pm 0.04$ & $7.55 \pm 0.24^{\star}$ & $8.47 \pm 0.10$ \\
\hline Frontenac - red & $10.28 \pm 0.06$ & $10.04 \pm 0.03$ & $9.80 \pm 0.04^{*}$ \\
\hline Seyval Blanc - white & $8.87 \pm 0.02$ & $8.06 \pm 0.09^{\star}$ & $8.51 \pm 0.00$ \\
\hline \multicolumn{5}{|c|}{ Volatile acidity [acetic acid g/L] } \\
\hline Marechal Foch - red & $0.26 \pm 0.01$ & $0.42 \pm 0.02^{\star}$ & $0.27 \pm 0.02$ \\
\hline Frontenac - red & $0.25 \pm 0.01$ & $0.28 \pm 0.01$ & $0.36 \pm 0.02^{*}$ \\
\hline Seyval Blanc - white & $0.20 \pm 0.00$ & $0.35 \pm 0.05^{*}$ & $0.27 \pm 0.02$ \\
\hline \multicolumn{5}{|c|}{$\mathrm{pH}$} \\
\hline Marechal Foch - red & 3.37 & $3.64 \pm 0.06^{*}$ & $3.49 \pm 0.01$ \\
\hline Frontenac - red & 3.07 & $3.27 \pm 0.02$ & $3.15 \pm 0.00$ \\
\hline Seyval Blanc - white & 2.43 & $3.27 \pm 0.03^{*}$ & $3.28 \pm 0.01$ \\
\hline
\end{tabular}

product. According to the Polish standard, acidity of the wine should be between 3.5 and $9 \mathrm{~g} / \mathrm{dm}^{3}$ based on tartaric acid. On the other hand, the volatile acidity should be up to $1.2 \mathrm{~g} / \mathrm{dm}^{3}$ in acetic acid for white wines and $1.4 \mathrm{~g} / \mathrm{dm}^{3}$ for red wines. After MLF by tested microorganisms, a decrease of total acidity was observed, with statistically significant changes noted for O. oeni in Marechal Foch (red wine) and Seyval Blanc (white wine), and for Lb. acidophilus in Frontenac (red wine) (Table I). Similarly, a statistically significant change in the volatile acidity was observed for O. oeni in Marechal Foch and Seyval Blanc, and for Lb. acidophilus in Frontenac. Interestingly, a statistically significant change was noted in the $\mathrm{pH}$ of Marechal Foch and Seyval Blanc, following deacidification by O. oeni.

Increasingly, it is believed that in addition to O. oeni as well as various species of Lactobacillus spp. could be used for MLF (Dicks and Endo, 2009), as starter cultures. They influence the formation of taste and smell through their involvement in the metabolism of citrate, amino acids, polysaccharides, polyhydric alcohols, aldehydes catabolism, hydrolysis of glycosides, the synthesis and hydrolysis of esters, degradation of phenolic acids, lipolysis, proteolysis and peptidolysis (Liu, 2002). Our results are in concordance with other experiments (Du Toit et al., 2011) and indicate the possibility of using various $\mathrm{LAB}$ species in the microbial process of wine deacidification. Interesting effects can be achieved using mixed starter cultures of $\mathrm{LAB}$, which will require further studies. The use of starter cultures consisting of different species of homo- and heterofermenting LAB would provide numerous benefits for wine producers.

Microflora of different varieties of grapes grown in cool climates and finished wines are characterized by high species diversity. Isolated common types of bacteria are lactic acid and acetic acid bacteria, cocci, aerobic bacilli and rods. Among the studied microflora, the lactic acid bacteria O. oeni, L. acidophilus and L. delbrueckii have been isolated; the first two have been used for microbiological deacidification of wines produced from national grape varieties. In the process of microbial deacidification of domestic wines, decreases of total acidity and increases of volatile acidity were observed, with statistically significant changes noted for O. oeni in Marechal Foch and Seyval Blanc, and for Lb. acidophilus in Frontenac. On the other hand, a statistically significant increase in $\mathrm{pH}$ was observed in Marechal Foch and Seyval Blanc after deacidification by O. oeni. Interesting results can be achieved using mixed starter cultures of lactic acid bacteria, which would provide control over the process, the specific flavor and aroma of wine, and microbiological stability.

\section{Literature}

Burbianka M., A. Pliszka, E. Janczura, T. Teisseyre and H. Załeska. 1971. Food Microbiology. Microbiological methods of alimentary testing (in Polish). PZWL, Warszawa.

Dicks L.M.T. and A. Endo. 2009. Taxonomic status of lactic acid bacteria in wine and key characteristics to differentiate species. S. Afr. J. Enol. Viticult. 30: 72-90.

Du Plessis H.W., L.M.T. Dicks, I.S. Pretorius, M.G. Lambrechts and M. Du Toit. 2004. Identification of lactic acid bacteria isolated from South African brandy base wines. Intern. J. Food Microbiol. 91: 19-29.

Du Toit M., L. Engelbrecht, E. Lerm and S. Krieger-Weber. 2011. Lactobacillus: the next generation of malolactic fermentation starter cultures - an overview. Food Bioprocess Technol. 4: 976-906.

Dworkin M., S. Falkow, E. Rosenberg, K.H. Schleifer and E. Stackebrandt. 2006. The Prokaryotes: A Handbook on the Biology of Bacteria. $3^{\text {rd }}$ ed. Springer Science and Business Media Inc. Singapore. 
Fleet G.H. 2007. Wine, pp. 863-890. In: Doyle M.P. and L.R. Beuchat (eds). Food Microbiology Fundamentals and Frontiers. $3^{\text {rd }}$ ed. ASM Press, Washington.

Gotcheva V., S.S. Pandiella, A. Angelov, Z.G. Roshkova and C. Webb. 2000. Microflora identification of the Bulgarian cerealbased fermented beverage boza. Process Biochemistry 36: 127-130. Henick-Kling T. 1995. Control of malolactic fermentation in wine: energetics, flavour, modification, and methods of starter culture preparation. J. Appl. Bacteriol. Supplement 79: 29S-37S.

Irudayaraj J., H. Yang and S. Sakhamuri. 2002. Differentiation and detection of microorganisms using Fourier transform infrared photoacoustic spectroscopy. J. Mol. Struct. 606: 181-188.

Liu S.Q. 2002. Malolactic fermentation in wine - beyond deacidification. J. Appl. Microbiol. 92: 589-601.

Parish M.E. and R.M. Goodrich. 2005. Recovery of presumptive Alicylobacillus strains from orange fruit surfaces. J. Food Protec. 68: 2196-2200.
PN-90/A-79120/04. Wines and meads. Preparation samples of the test. Determination of ethyl alcohol (in Polish).

PN-90/A-79120/07. Wines and meads. Preparation samples of the test. Determination of total acidity (in Polish).

PN-90/A-79120/08. Wines and meads. Preparation samples of the test. Determination of volatile acidity (in Polish).

Ponce A.G., S.I. Roura, C.E. del Valle and R. Fritz. 2003. Characterization of native microbial populations on Swiss chard (Beta vulgaris, type cicela) cultivated by organic methods. LebensmittelWissenschaft und-Technologie 36: 183-188.

Pozo-Bayon M.A., E. G-Alegria, M.C. Polo, C. Tenorio, P.J. MartinAlvarez, M.T. Calvo de la Banda, F. Ruiz-Larrea and M.V. Moreno-Arribas. 2005. Wine volatile and amino acid composition after malolactic fermentation: effect of Oenococcus oeni and Lactobacillus plantarum starter cultures. J. Agric. Food Chem. 53: 8729-8735. 